\title{
PSYCHOLOGICAL ANALYSIS OF PARADIGMS OF DEVELOPMENT OF MODERN HIGHER EDUCATION
}

\author{
Halyna Radchuk \\ Ternopil Volodymyr Hnatiuk National Pedagogical University, Ukraine \\ Zoryana Adamska \\ Ternopil Volodymyr Hnatiuk National Pedagogical University, Ukraine \\ Solomiia Chopyk \\ Ternopil Volodymyr Hnatiuk National Pedagogical University, Ukraine \\ Halyna Sviderska \\ Ternopil Volodymyr Hnatiuk National Pedagogical University, Ukraine
}

Viktoria Oleksiuk

Ternopil Volodymyr Hnatiuk National Pedagogical University, Ukraine

\begin{abstract}
The article presents a theoretical and methodological analysis of modern educational paradigms and presents axiological vectors of higher education development. The authors identify four basic educational paradigms: cognitive informational, personal (humanistic), competence based and cultural (humanitarian). It has been found that, unlike instrumentoriented learning, which provides the translation, reproduction and assimilation of knowledge, skills, technologies (cognitive informational and competence paradigms) and therefore is secondary to the processes of personality development, education should firstly be focused on development of a holistic personality, ensuring its nature and uniqueness (personal and cultural paradigms). It has been proven that at the theoretical level there has been a drastic narrowing of the semantic field of scientific and pedagogical reflection: the focus is on the production of the amount of knowledge, programmed social behaviour, technologies of activity of the future specialists. It has been shown that higher education institutions are more and more inclined to provide pragmatic education, and training professionals-functionaries. It is determined that the reform of modern education should be based on the idea of integrity, which actualises the problem of careful reflexive and methodological support of the modern higher education system and the development of specific humanitarian educational technologies.
\end{abstract}

Keywords: Education, educational paradigm, cognitive informational paradigm, personal paradigm, competence paradigm, cultural paradigm.

\section{Introduction}

The search for new approaches to enhance the compliance of higher education with the requirements of the twenty-first century has become a leading feature of the current stage of its development. The importance of research in this 
Radchuk et al., 2021. Psychological Analysis of Paradigms of Development of Modern Higher Education

sector is determined by the high social importance and perspective of national higher education development in the context of Ukraine's accession to the European educational space.

That is why the problem of clarifying and concretising the educational paradigm of higher education, identifying the main characteristics of the modern educational process through consideration of education in a broad socio-cultural context is quite acute today.

The development of education is based on broad philosophical ideas and is filled with philosophical content. The philosophy produces the creation of new educational concepts, setting the direction of scientific search, acting as a methodological basis for the development of new educational theories.

The formation of a new conception of education in the early 21st century is associated with the emergence of a new philosophical picture of the world based on recognition of its openness and self-organization. The philosophy of education examines development of a person in a cultural environment and how educational system can (and should) contribute to this process.

Therefore, the aim of the study is to analyze existing educational paradigms in a philosophical context, which will help to identify the main axiological vectors of higher education development.

Research methodology. The authors have done an interdisciplinary analysis and thorough theoretical and methodological reflection of modern scientific discourse of paradigms in modern education development, its essential values, as well as its systematic consideration in the context of modern paradigmatic changes, based on the review of psychological and psychological literature.

\section{Literature Review}

Hereinafter the educational paradigm will be interpreted as a set of established meaningful characteristics that determine the essential features of educational activity models and interaction between participants of the educational process.

The problem of finding a new educational paradigm is particularly relevant within the framework of the philosophy of education. It is worth noting that in philosophical literature the traditional understanding of educational process has been criticised as a kind of "social inheritance", a process of ascending on the "civilisation ladder", focused on "production" of people with predetermined qualities. Psychologists and educators also unanimously agree on the fact that educational process is often described as a process of technical production according to officially recognised and pre-known criteria and models.

In modern philosophy the orientation on overcoming the Scientian position to stop the negative processes in education is clearly outlined. Philosophers are 
concerned about rapid devaluation of the apex values. Thus, analysing value orientations of modern education, philosophers emphasise the ability to awaken the "human" in a person (their spirituality, desire for self-knowledge, selfdevelopment) as the most important criterion for its effectiveness (Gusinsky, 2000; Kagan, 2007).

While studying educational paradigms, E. Gusinsky and Y. Turchaninova came to the conclusion that the diverse educational values can be divided into two main groups: (1) the value of preserving the existing order of things and (2) the value of its transformation (Gusinsky, 2000).

\section{Research Results}

Interdisciplinary analysis and profound theoretical and methodological reflection resulted in stating that the understanding of the concept of "education" is being narrowed, which is a serious obstacle to the implementation of the essential values of education. This led to a systematic examination of higher education in the context of contemporary paradigm changes and a profound immersion into the analysis of philosophical, sociological, cultural, psychological and pedagogical sources.

Thus, in general, it can be stated that the discussion, which has been developed around the values of modern education reflects the clash of four educational paradigms: cognitive informational, personal, cultural and competence related. Each of these paradigms reproduces only part of the reality adequately and focuses its attention on what can be considered the result of education.

The cognitive informational (cognitive, traditional) paradigm reflects the necessity of transferring the maximum amount of all knowledge and skills accumulated by the mankind to a personality. It interprets orientation of the educational process in a certain way, directing teachers to subject programs, fixed results, etc. Therefore the desires, personality needs, as a rule, are not taken into account. This paradigm is based on a powerful tradition dating back to Aristotle. Psychologists have already evaluated the cognitive informational paradigm of education as maladaptive for the individual.

It is generally known that the traditional model of education is too static, monologue based, and oriented towards the disciplinary distinction of knowledge in the form of relatively autonomous, closed systems of information retention, which should be "embedded" into students' heads. This model is largely closed and virtually incapable of development, and therefore becomes increasingly inadequate to the modern realities of the global change process. The consequence of this is not only the fragmentation of reality perception, but also its deformation, which in the conditions of post-industrial information society does not allow 
Radchuk et al., 2021. Psychological Analysis of Paradigms of Development of Modern Higher Education

people to respond adequately to the ecological crisis, leads to the devaluation of moral norms and values.

The personal paradigm is concentrated on the emotional and social development of the person. The essence of a personally oriented paradigm of education lies in considering a person to be a complex self-organised system, in recognising the uniqueness, self-worth of each human and the vector of their development; in shifting of educational goals from the informatisation of a personality to creating conditions for their self-determination and selfdevelopment; in development of a subjective position of a teacher in the educational process, which should provide personal meaning to learners' activities, create space for manifestation and development of their individuality, and give freedom of choice. Personality oriented technologies are of particular importance because they emphasise the value of an individual, produce a positive attitude towards people and oneself, indicate the need for partnership in relationships, imply the development of spiritual qualities of an individual, respect and care for each person, empathy, ability to co-exist, naturalness and openness of relationships as a significant indicator of personal development (Rodgers \& Freberg, 2002).

Thus, the humanisation of education, on the one hand, is a condition for harmonious development of an individual, the enrichment of creative potential, the growth of essential forces and abilities, and on the other hand - a process aimed at development of an individual as a subject of creative activity. At the same time, the humanisation of education is an important characteristic of lifestyle of educators and students, which involves establishing genuine human relationships between them in the learning process.

At the same time scientists are looking for and developing cultural models of education (Asmolov, 1996; Bondarevskaya, Ivanova, \& Osmolovskaya, 2005). The main function of these models is the humanitarian one, which is to preserve and restore human ecology, physical and spiritual health, the meaning of life, personal freedom and morality. Within the cultural paradigm a teacher has to be focused on the main task - development of a child's personality. This paradigm dictates that achievement of completeness and integrity of the worldview goes far beyond pragmatic cognitive pedagogy. Its main task is In upbringing of a spiritual person.

E. Bondarevskaya notes: "Education must be filled with cultural meanings. The cultural meanings of education are supposed to be human” (Bondarevskaya, Ivanova, \& Osmolovskaya, 2005, p. 116). Thus, she puts meaning-making, holistic understanding, and personal knowledge on the first position in education. Education is intended to create a space for cultural development, a field for interaction of ideal (cultural) and real sensory forms. The main and the most essential tasks of modern education lie in helping a person to make a dialogue 
with other cultures, people, in comprehending and feeling their values, in listening to own inner voice, in realising oneself, the meaning of one's own existence and in definition of one's own place in culture, and, therefore, in life.

The competence paradigm grows from the cognitive informational one. However, unlike the last one, there is an awareness of the impossibility and meaninglessness of the infinite dissemination of information passed on to future generations. The expected result of the educational process is not presented by a system of knowledge and skills, but by a set of key, declared competencies without which the activity of a modern person in the intellectual, social, political, communicational, informational and other spheres becomes impossible. The competence paradigm is aimed at enhancing the practical orientation of education; training a well skilled and mobile person, who owns not a set of facts, but methods and technologies needed for obtaining them.

We believe education must reproduce a coherent entity of culture and activity, a person in its existential and ontological fullness. Unlike instrumentoriented learning, which provides translation, reproduction and assimilation of knowledge, skills, technologies (cognitive informational and competence based paradigms) and therefore is secondary to the processes of personality development, education must firstly be focused on the development of a coherent person, ensure their identity and uniqueness (personal and cultural paradigm). If higher education excludes the spiritual and moral essence of a person and is focused only on transferring of the maximum amount of knowledge and assimilating of technologies, it does not ensure the professional success of a specialist and inevitably leads to a socio-cultural and personal identity crisis.

In our view, within the system of cognitive informational and competence based paradigms, a person is perceived not in his/her identity and integrity, but through the filter of functionally defined parameters - success, discipline, behaviour, etc. Therefore, the cognitive informational component of education must be instrumental in its core value - cultural, value-meaning development of an individual.

While analysing the crisis state of modern education, M. Kagan notes that it primarily occurs because of neglecting of holistic and systemic structure of the human psyche, which existence and functioning in the process of education is ensured by implementation of five major activities:

1) "cognitive, the aim of which is to obtain the information about the object by the subject; the highest form of it is science in all its modifications, from mathematics to psychology;

2) value-oriented, the aim of which is the object's awareness of the subject's value; the highest form of it is ideology in all its various modifications, from religious to aesthetic; 
Radchuk et al., 2021. Psychological Analysis of Paradigms of Development of Modern Higher Education

3) transformative, the aim of which is to change the object by the subject; the highest form of it is material, practical and spiritual-ideal activity resulting in creation of a new cultural object from natural, social, human given material...;

4) communication as an interpersonal interaction, the aim of which is to achieve the unity of subject and object while maintaining the subjective uniqueness of each (it can be an interpersonal or an intergroup dialogue, when a social group, for example a creative team or a nation, acts as an "aggregate entity", and an intrapersonal dialogue, when personalities are polysubjective and their consciousness serve as an arena for internal dialogue;

5) artistic perception of the world, in which all four homogeneous activities mentioned above are syncretically merged in mythological consciousness and in the perception of a child, and later syncretically mutually identified in art” (Kagan, 2007, 228).

Current education does not ensure functioning of all five activities, focusing only on development of cognitive and analytical abilities of an individual. First of all, this is ensured by the implementation of cognitive informational and competence paradigms. Spiritual life is reduced to the ability to learn and develop useful rational functions.

According to E. Fromm, any educational paradigm can be correlated with one of the modes of human existence - "to be" or "to have". Modus "to have" involves the change of external to human circumstances and alienated activity aimed at changing these circumstances for the sake of mastering things, the unrestrained consumption of them, and power over them. Possession is also the perception of one's inner world as a subject matter. In education, this is reproduced as an orientation towards "having more knowledge", because those enriched with knowledge are more likely to gain material things. Consumption of knowledge, according to E. Fromm, in fact, turns out to be an empty occupation, since there is no internal activity, which, does not necessarily have to be expressed externally (Fromm, 2017, 118).

Modus “to be” implies a person's self-change, internal, spiritual-personal self-growth, and inalienable activity, aimed at being open and involved in the world. In education, this is reproduced as a focus on "knowing more deeply"; on comprehending holistic world and oneself in this world based on cognitive interest; on exploring phenomena through giving them a personal meaning. Such "meaningful teaching", according to K. Rogers, is not focused on the external result, but rather on a sense of health and creative harmony of the inner and outer harmony of a person with oneself, with other people and with the world in general (Rodgers \& Freberg, 2002). 
Thus, the dialectic of education is expressed not in some completed knowledge base of an individual, but in openness to the development and selfcreation. The inherent openness, and orientation towards someone or something leads an individual to finding the meaning of own existence. The principle of openness is one of the basic principles of cognition. A well-known Ukrainian philosopher and psychologist V. Romenets states: "The openness of a person lies not in the fact that he/she can be opened as a turtle, but in the fact that he/she opens her/himself, spreading to the entire world that is accessible to him/her. This world comes into him/her as a certainty. He/she opened it, not from the outside, but from the inside" (Romenets, 2006, 23). Open knowledge is theoretical, empirical, sensual, intuitive, and rational, based on an array of authoritative data.

Philosophers point out that today there is a growing conflict between the utilitarian technocratic view of education on the one hand, and the need for a democratic society to provide opportunities for individual human development on the other; between the recognised need for personal growth in the education system and the widespread need for knowledge transfer; between the demand for learning freedom and the rigid framework of the traditional system.

The challenge the educational sphere faces in the 21st century is the understanding of the synergetic theory and related key thesis about the open nature of any social system, in particular, the educational one. Therefore, unlike all previous "scientific paintings", in the synergistic picture of the world, the starting point is variability, processivity, the formation of a new whole - that is, everything that characterises the processes of self-organisation that take place in nonlinear environments. Self-organisation reveals the essence of the process more precisely and more fully, since the reaction to external influences depends not only on the magnitude of this influence, but also on the inherent properties of the system (Kagan, 2007).

Taking into account the synergistic principle of self-organisation of open systems expands the possibilities of analysis of education modeling, creates the most optimal conditions for its systematic understanding. Indeed, today, like never before, there is a need for a holistic view on education, with an emphasis on the dynamics and mechanisms of self-organisation of the subjects of the educational space, the unity of education and upbringing, the education of a holistic creative personality. At the same time such universal human values as freedom and creativity are the most important values of modern education. Freedom, as an opportunity to act in the absence of external direction, and creativity, as a human activity to create new qualities, knowledge, meanings, become the basic axiological dimensions of education.

Thus, in the context of the synergistic paradigm methodology, the center of research and modeling of educational systems shifts towards internal mechanisms of development. In addition, the essence of the individual, who is included in the 
Radchuk et al., 2021. Psychological Analysis of Paradigms of Development of Modern Higher Education

holistic system of education is examined through the lens of synergistic vision. In fact, synergetics illuminates the spontaneity of self-unfolding of the individual's inner content.

It is important to emphasize that, from a synergistic point of view, meaning and context cannot, in principle, be submitted to the student in a pre-made form, given from the outside, but requiring internal self-organisation. Therefore, it can be argued that the synergistic foundations of education require creation of a new, open system of education, where a person reveals themselves. Synergetics poses the need for development of a new paradigm of education, which allows to move from the process of giving students a certain minimum of knowledge, to master the educational standard, to their immersion in the problem of human relations with nature and society.

Therefore, if we are to consider the phenomenon of education in a broad socio-cultural context, then education is always and in each case means the possibility to reveal own essential forces of an individual. This possibility is realised by an individual in search of the sense of being. Thus, there is another fundamentally important point in the analysis of educational intents. "To be a man, - writes W. Frankl, - means to go beyond oneself ... the essence of human existence lies in his/her self-transcendence” (Frankl, 2020, 51).

Indeed, in the context of the transition to the information society, when "information becomes more and less meaningful" (Baudrillard, 2004, 121), the task of education is to create the conditions for the realisation of a person's desire for getting a meaning, its identification and comprehension. In this case, it is not just about adapting to existing social experience, reproduction of knowledge, but about developing one's own existential position in the process of education (Baudrillard, 2004).

A. Asmolov draws attention to the fact that in general, today there are two basic paradigms in education - "informational, command, and semantic, creative. When we choose one of these paradigms we choose the future, the culture we want to live in - totalitarian or humanistic, the culture of Utility or the culture of Dignity" (Asmolov, 1996, 676). In his opinion, education, which is pragmatically focused on a model of a specialist, forms a depleted one-sided personality; the information overload, which is inherent in the scientific and technical age, brings the educational system to a standstill of "substantive self-centeredness". The only way out is to "embark on a different path, the path of a meaningful and creative paradigm in education" (Asmolov, 1996, 677). Therefore, to find the sense of life is possible in education, "which creates a meaningful picture of the world and helps make life decisions in uncertain situations" (Asmolov, 1996, 678).

The relevance of the mentioned above theses is multiplied by the sociocultural crisis of our society, the disintegration of the usual value system, the changing of stereotypes in a professional career building and professional 
development. Analysing the process of higher vocational education, we can formulate the following contradictions:

- between the declared in pedagogical practice orientation on the student's personality development, and the dominance of the classical educational paradigm in teachers' training, aimed at subject preparation, assimilation of constantly increasing amount of knowledge and skills;

- $\quad$ between the need to create conditions for the development of students as future professionals and the dominant focus on them as objects of pedagogical influence;

- $\quad$ between the need for spiritual and value-emotional development of a future specialist's personality and the lack of psychological and pedagogical conditions and mechanisms that provide the solution to this problem in the process of studying in a higher educational institution (Radchuk, 2014).

The real process of higher vocational education indicates a serious deformation of the professional formation of a personality of a future specialist, which leads to deformation of human consciousness - the alienation of an individual from own personality, loss of professional sense, future prospects, helplessness and devastation. Researchers focus on the disturbing tendency in the development of a humanitarian aspect of educational content, which is reflected in verbalisation and rationalisation of education. Information overload blocks affective-emotional sphere of an individual, prevents adequate, holistic perception of reality, and formation of an emotional contact with it. Inidividuals' emotional world, their creative potential, productive thinking is actually superseded by the dominance of information.

The problem of higher vocational education of the humanitarian professionals is becoming extremely urgent as there are serious requirements for their moral qualities and values development. Higher pedagogical education, according to M. Kagan, focuses primarily on the "training of a "subject teacher", has more or less effective teaching methods to teach the basics of a subject, but not a so-called "teacher-creator", who shapes the Person as a whole and unique Individual who responds to the demands of a new historical type of 21st century's culture” (Kagan, 2007). Having analysed the process of future psychologists' training, G. Breslav raises the logical question of how one can be attached "to the values of "non-directional psychology" in a rather rigid training model, which nevertheless is closer to the ideology of "preparation" rather than "education" (Breslav, 1997, 252). 
Radchuk et al., 2021. Psychological Analysis of Paradigms of Development of Modern Higher Education

Therefore, there is a need to overcome one-sided technocratic tendencies in professional training of future specialists, which are manifested in insufficient consideration of their personal development (Radchuk, 2017).

\section{Conclusions}

On the basis of theoretical and methodological analysis, there have been four basic educational paradigms identified: cognitive-informational (traditional, cognitive), personal (humanistic), competent and cultural (humanitarian). It is found that, unlike instrument-oriented learning, which provides translation, reproduction and assimilation of knowledge, skills, technologies (cognitiveinformation and competence paradigms) and therefore is secondary to the processes of personality development, education should first and foremost be focused on the development of a holistic personality (personal and cultural paradigms).

It can be stated that at the theoretical level there has been a drastic narrowing of the semantic field of scientific and pedagogical reflection: the focus is drawn to production of the sum of knowledge, programmed social behaviour, technologies of a future specialist's activity. Insufficient understanding of the essential aspects of educational process leads to an inclination towards formal, technological aspects, and to overly enthusiastic attitude in calculating points and credits.

In such conditions, the education in its humanitarian sense suffers, and the quality of education is often reduced to the level of mastering professional knowledge and skills. Higher education institutions are increasingly inclined to pragmatic training of professional functionaries. However, the main goals of modern higher education should lie in the cultural orientations which allow substituting knowledge approach by a meaningful one, where both the teacher and the student are active participants of educational activity.

The reform of education should be based on the idea of the integrity of education, which actualises the problem of careful reflexive and methodological support of the modern higher education system and the development of specific humanitarian educational technologies.

\section{References}

Asmolov, A. G. (1996). Kul'turno-istoricheskaja psihologija i konstruirovanie mirov. Moskva: Institut prakticheskoj psihologii, MODJeK.

Bodriyar, Zh. (2004). Symvolichnyj obmin i smert". Lviv: Kal"variya.

Bondarevskaya, E.V., Ivanova, E.O., Osmolovskaya, I.M. (2005). Teorija i praktika lichnostnoorientirovannogo obrazovanija. In O.E. Ivanova, I.M. Osmolovskaja (Ed.), Lichnostno- 
orientirovannoe obuchenie: Hrestomatija (pp. 116-162). Moskva: Sovremennyj gumanitarnyj universitet.

Breslav, G.M. (1997). Obrazovanie i podgotovka psihologov: dilemmy gumanisticheskoj psihologii. In D.A. Leont'ev \& V.G. Shhur (Ed.), Psihologija s chelovecheskim licom: gumanisticheskaja perspektiva v postsovetskoj psihologii (249-256). Moskva: Smysl.

Gusinsky, E.N., Turchaninova, Ju.I. (2000). Vvedenie v filosofiju obrazovanija: Uchebnoe posobie. Moskva: Logos.

Kagan, M.S. (2007). Sistemno-sinergeticheskij podhod $k$ postroeniju sovremennoj pedagogicheskoj teorii. In V.G. Budanov (Ed.), Sinergeticheskaja paradigma. Sinergetika obrazovanija (212-245). Moskva: Progress-Tradicija.

Radchuk, H.K. (2014). Aksiopsyxolohiya vyshhoyi shkoly: Monohrafiya. Ternopil": TNPU im. V. Hnatyuka.

Radchuk, H.K. (2017). Osvitnij dialoh yak innovacijna humanitarna texnolohiya profesijnoho stanovlennya osobystosti. Pedahohichnyj proces: teoriya i praktyka. Zbirnyk naukovyx prac", 1 (56). Retrieved from: http://nbuv.gov.ua/UJRN/pptp_2017_1_4

Rodgers, K., Frejberg, Dzh. (2002). Svoboda uchit'sja, A. B. Orlov (Ed.). Moskva: Smysl.

Romenets, V.A. (2006). Vchynok i postannya kanonichnoyi psyxolohiyi. In V.O. Tatenko (Ed.), Lyudyna. Sub’yekt. Vchynok: Filosofs"ko-psyxolohichni studiyi (11-36). Kyyiv: Lybid".

Frankl, V. (2020). Lyudyna v poshukax spravzhn"oho sensu (O. Zamojs"ka, Trans.). Xarkiv: Knyzhkovyj klub "Klub Simejnoho Dozvillya".

Fromm, E. (2017). Mystectvo lyubovi (V. Kuchmenko, Trans.). Xarkiv: Knyzhkovyj klub "Klub Simejnoho Dozvillya". 